\title{
IMPLEMENTATION OF THE SAVING MATRIX METHOD TO DETERMINE VEHICLE ROUTES
}

\section{Rifan Rizwan, Willy Rizkilah Ramdani, Muhammad Faisal Khobir and Muchammad Fauzi}

Widyatama University

Email: rifan.rizwan@widyatama.ac.id,willy.rizkilah@widyatama.ac.id, faisal.khobir@widyatama.ac.id, muchammad.fauzi@widyatama.ac.id

\begin{tabular}{ll}
\hline Keywords & Abstract The availability of the number of vehicles in \\
Distribution, & Karawang Regency is not matched by the availability of \\
Transportation, & fuel at gas stations. Due to the very high demand for \\
Saving Matriks & fuel, the Cikampek BBM Terminal has several problems, \\
Article Info & including the absence of a standard distribution route in \\
Accepted: & distributing its products to gas stations so that it takes a \\
June, $\mathbf{2 1}^{\text {st }} \mathbf{2 0 2 1}$ & long time and the high amount of transportation costs \\
Revised: & that must be borne by the company. In this study, the \\
July, $\mathbf{1}^{\text {st }} \mathbf{2 0 2 1}$ & route and distribution schedule will be determined as \\
Approved: & well as determining the capacity and number of tanker \\
July, $\mathbf{9}^{\text {th }} \mathbf{2 0 2 1}$ & trucks that are able to minimize mileage, travel time and \\
& transportation costs. Based on calculations using the \\
& Saving Matrix method, it produces efficiency in the \\
& number of vehicles needed from 7 trucks to 4 tanker \\
& trucks, vehicle usage from 9 times to 6 times, distance \\
& traveled from 63 KM to 53 KM and the difference in \\
transportation costs per day is Rp. 1,312,633.
\end{tabular}

\section{Introduction}

Distribution management is one of the factors that must be considered by companies for product distribution to consumers (Suryanto \& SE, 2016). So it plays an important role in the company. Because in meeting customer demand, it is not enough to just fulfill the total demand, but also service problems, the timeliness of product delivery is the main concern of consumers (Adriantantri, Irawan, \& Indriani, 2015). Distribution costs can be reduced by calculating all factors correctly so that time, distance and energy are used efficiently and effectively. 


\section{Rifan Rizwan, Willy Rizkilah Ramdani, Muhammad Faisal Khobir and Muchammad Fauzi}

Adequate transportation is closely related to distribution (Salsabila, 2021). For this reason, it is necessary to clearly know the distribution channel, total customer demand and the capacity of the transportation means used, so that distribution can be carried out efficiently and effectively (Momon \& Ardiatma, 2018).

PT PERTAMINA (Persero) Cikampek BBM Terminal in distributing its products to gas stations in Cikampek has several problems, one of which is the high total transportation costs that must be borne by the company. Coupled with the absence of a clear standard distribution route so that gas stations have to wait for a long supply of fuel from tanker trucks that are distributing to other gas stations because the truck must first return to the depot for refilling and the distribution schedule is inconsistent every day (Supardi \& Sianturi, 2020).

To anticipate this problem, a method is needed that can provide minimal product distribution costs (MOCHAMAD ARIF WIBOWO, 2019). The Saving Matrix method is a method used to determine product distribution routes to marketing areas by determining the distribution routes that must be passed and total vehicles based on vehicle capacity in order to obtain the shortest route and minimal transportation costs (Tyas, Dzulqarnain, \& Aini, 2020).

Distribution Management is a matter that covers all aspects of the process of delivering products to consumers, because this activity is very important in the marketing system, effective and efficient distribution can accelerate goods to be marketed (Suryanto \& SE, 2016). According to Suhardi Sigit, the distribution channel is a path traversed by the flow of goods from producers to intermediaries to consumers (Laksono, 2017). Manufacturers must consider various factors that are very influential in the selection of distribution channels. The selection of an effective distribution channel will be able to encourage the expected increase in sales, so that the survival of the company can be guaranteed (Mardhiyah \& Safrin, 2020).

Transportation is defined as the business and activity of transporting or carrying goods and or passengers from one place to another (Yasmin \& Wirawan, 2018). In addition, the carriage or transfer of passengers or goods by transportation is to reach the destination and increase the utility or usability of the goods being transported. Each form of transportation has four main elements of transportation, namely roads, vehicles and means of transportation, propulsion, and terminals (Munawar, n.d.). In the modern transportation system, transportation is an integral part of the functions and activities of society. There is a very close relationship with lifestyle, range, location of production activities, fulfillment of goods, and services available for consumption (Suparjo, 2017). 
This research at PT Pertamina Terminal BBM Cikampek will arrange distribution routes and schedules and determine the capacity and total tank truck vehicles that are able to minimize mileage, travel time, and transportation costs. Some of the benefits from the results of this study are expected to provide useful input and information for the company, including knowing an effective and efficient premium distribution schedule so that it can speed up delivery, minimize transportation costs, and increase company profits, then be able to determine the capacity and total truck vehicles. the right tank according to the total demand for premium so that the problem of high demand can be resolved, and can find out the distribution route that can be a distribution standard for every day so that it can facilitate the delivery of fuel to gas stations.

\section{Research Method}

The Savings Matrix method is also one of the techniques used to schedule a limited total of vehicles from facilities that have a maximum capacity (Erlina, 2009). The Saving Matrix method consists of several steps. According to (Istantiningrum, 2010) the steps in the saving matrix method are as follows:

1. Determining the Distance Matrix In determining the distance matrix, data on the distance between the company and the location of the destination is very necessary. After knowing the coordinates of each location.

2. Determine the Saving Matrix

After knowing the overall distance, namely the distance between the company and other destination locations, that in this step it is assumed that each location will be passed by one truck specifically.

3. Allocation of Vehicles and Routes by Location

After the results of the saving matrix are known, the next step is the allocation between locations to routes or vehicles.

The research was conducted by PT. Pertamina Cikampek BBM Terminal which carries out the distribution of BBM (Fuel Oil). The data collection method used is Interview, then conduct a review or direct observation to the field by taking data on the related company. Total delivery data, total vehicles and total customers are taken from the data for the last 3 months. Conducting interviews with related parties to find out the existing problems in order to map the system as a whole in the distribution process with actual time and data. And the final stage is the conclusion of the overall research that has been done and suggestions for the development of research in the future.

\section{Result and Discussion}

PT. PERTAMINA (Persero) Cikampek BBM Terminal has a distribution area in Kab. Karawang. Pertalite is a product that is needed in the community, so the demand 


\section{Rifan Rizwan, Willy Rizkilah Ramdani, Muhammad Faisal Khobir and Muchammad Fauzi}

for pertalite is high. The average daily demand for pertalite and a list of gas stations in the Kab. Karawang and the distance data from the depot to each gas station taken from google maps can be seen in Table 1. Distribution of fuel to gas stations PT. Pertamina Cikampek BBM Terminal uses tanker trucks. Tank trucks available at the company are trucks with a capacity of 3 units of 16 kiloliters and 4 units of 24 kiloliters. A truck with a capacity of 24 kiloliters has a higher fuel cost than a truck with a capacity of 16 kiloliters.

One tanker truck requires 1 driver and 1 assistant. In this study, transportation costs consist of variable costs and fixed costs, salaries for drivers and assistants, including fixed costs. Fixed costs will decrease if the number of drivers and assistants is reduced by reducing the number of tanker trucks. Salaries of drivers and assistants within 25 days are presented in table 1.

Table 1. Number of requests and distance from TBBM to gas stations

\begin{tabular}{ccc}
\hline SPBU Code & Request (Kiloliter) & $\begin{array}{c}\text { Distance from TBBM to } \\
\text { SPBU (KM) }\end{array}$ \\
\hline 34.41305 & 20 & 1.7 \\
34.41304 & 29 & 7.3 \\
34.41307 & 31 & 1.3 \\
34.41332 & 30 & 3 \\
34.41315 & 32 & 3.2 \\
\hline Total & 142 & \\
\hline
\end{tabular}

Table 2. Truck Cost Data per Kilometer

\begin{tabular}{cccccc}
\hline No & $\begin{array}{c}\text { Truck } \\
\text { Capacity }\end{array}$ & Usage & $\begin{array}{c}\text { BBM } \\
\text { Price }\end{array}$ & Distance & Cost per KM \\
\hline 1 & 16 & 1 & 9,500 & 3 & $3,166.667$ \\
2 & 24 & 1 & 9,500 & 2 & 4,750 \\
\hline
\end{tabular}

Table 3. Driver and Kernet Salary Data

\begin{tabular}{ccccc}
\hline No & Position & Salary & $\begin{array}{c}\text { Number of } \\
\text { Days }\end{array}$ & $\begin{array}{c}\text { Salary per } \\
\text { day }\end{array}$ \\
\hline 1 & Supir & $4,200,000$ & 25 & 168,000 \\
2 & Kernet & $4,000,000$ & 25 & 160,000 \\
\hline
\end{tabular}


Table 4. Data for the Distribution of Delivery Stages

\begin{tabular}{lccc}
\hline SPBU Code & $\begin{array}{l}\text { Request } \\
\text { (Kiloliter) }\end{array}$ & Phase 1 & Phase 2 \\
\hline 34.41305 & 20 & 20 & 0 \\
34.41304 & 29 & 24 & 5 \\
34.41307 & 31 & 24 & 7 \\
34.41332 & 30 & 24 & 6 \\
34.41315 & 32 & 24 & 8 \\
\hline
\end{tabular}

The system used in the distribution is direct shipment, for round trips, the distance from the depot to the gas station is multiplied by 2 .

Table 5. Transportation Costs Phase 1

\begin{tabular}{cccccc}
\hline Route & $\begin{array}{c}\text { Phase 1 } \\
\text { (Kiloliter) }\end{array}$ & $\begin{array}{c}\text { Cap. Tank } \\
\text { Truck } \\
\text { (Kilometer) }\end{array}$ & $\begin{array}{c}\text { Cost/KM } \\
\text { (Rp) }\end{array}$ & $\begin{array}{c}\text { Distance } \\
\text { From } \\
\text { Depot } \\
\text { (KM) }\end{array}$ & $\begin{array}{c}\text { Variable } \\
\text { Cost }\end{array}$ \\
\hline $0-1-0$ & 20 & 24 & 4,750 & 3.4 & 16,150 \\
$0-2-0$ & 24 & 24 & 4,750 & 14.6 & 69,350 \\
$0-3-0$ & 24 & 24 & 4,750 & 2.6 & 12,350 \\
$0-4-0$ & 24 & 24 & 4,750 & 6.0 & 28,500 \\
$0-5-0$ & 24 & 24 & 4,750 & 6.4 & 30,400 \\
\hline Total & 116 & & & 33 & 156,750 \\
\hline
\end{tabular}

Table 6. Transportation Costs Phase 2

\begin{tabular}{crrrrr}
\hline Code & $\begin{array}{c}\text { Phase 2 } \\
\text { (Kiloliter) }\end{array}$ & $\begin{array}{c}\text { Cap. Tank } \\
\text { Truck } \\
\text { (Kilometer) }\end{array}$ & $\begin{array}{c}\text { Cost/KM } \\
\text { (Rp) }\end{array}$ & $\begin{array}{c}\text { Distance } \\
\text { From } \\
\text { Depot } \\
(\text { KM) }\end{array}$ & $\begin{array}{c}\text { Variable } \\
\text { Cost }\end{array}$ \\
\hline $0-2-0$ & 5 & 16 & $3,166.7$ & 14.6 & 46,233 \\
$0-3-0$ & 7 & 16 & $3,166.7$ & 2.6 & 8,233 \\
$0-4-0$ & 6 & 16 & $3,166.7$ & 6 & 19,000 \\
$0-5-0$ & 8 & 16 & $3,166.7$ & 6.4 & 20,267 \\
\hline Total & 26 & & & 29.6 & 93,733 \\
\hline
\end{tabular}

Table 7. Number of trucks used

\begin{tabular}{lcccc}
\hline \multicolumn{2}{c}{ Vehicle } & $\begin{array}{c}\text { Total } \\
\text { Initial }\end{array}$ & Usage & $\begin{array}{c}\text { Number of } \\
\text { Queue }\end{array}$ \\
\hline Premium & $16 \mathrm{KL}$ & 3 & 4 & 1 \\
Premium & $24 \mathrm{KL}$ & 4 & 5 & 1 \\
\hline
\end{tabular}




\section{Rifan Rizwan, Willy Rizkilah Ramdani, Muhammad Faisal Khobir and \\ Muchammad Fauzi}

$\begin{array}{llll}\text { Total } & 7 & 9 & 3\end{array}$

From the calculation results, the total variable costs are obtained, namely the first stage transportation costs plus the second stage transportation costs. Total fixed costs are obtained from the total number of vehicles used.

$$
\begin{aligned}
\text { Total Variable Cost } & =\text { Rp. } 250,483 \\
\text { Total Fixed Cost } & =((7 \text { sopir } \times 168.000)+(7 \text { kernet } \times 160.000)) \\
& =\text { Rp. } 2,296,000 \\
\text { Total Transportation } & =\text { Total Variable Cost }+ \text { Total Fixed Cost } \\
& =\text { Rp. } 250,483+\text { Rp. } 2,296,000 \\
& =\text { Rp. } 2,546,483,-
\end{aligned}
$$

\begin{tabular}{|c|c|c|c|c|c|c|c|}
\hline & & 0 & 1 & 2 & 3 & 4 & 5 \\
\hline Depot & 0 & - & 1.7 & 7.3 & 1.3 & 3 & 3.2 \\
\hline 34.41305 & 1 & & & 6.9 & 1.5 & 0.5 & 1.9 \\
\hline 34.41304 & 2 & & & & 5.7 & 7.5 & 7.6 \\
\hline 34.41307 & 3 & & & & & 3.1 & 3.2 \\
\hline 34.41332 & 4 & & & & & & 0.8 \\
\hline 34.41315 & 5 & & & & & & \\
\hline
\end{tabular}

\begin{tabular}{|c|c|c|c|c|c|c|}
\hline & 0 & 1 & 2 & 3 & 4 & 5 \\
\hline 0 & - & & & & & \\
\hline 1 & & & 2.1 & 1.5 & 4.2 & 3 \\
\hline 2 & & & & 2.9 & 2.8 & 2.9 \\
\hline 3 & & & & & 1.2 & 1.3 \\
\hline 4 & & & & & & 5.4 \\
\hline 5 & & & & & & \\
\hline
\end{tabular}

Table 8. Distribution of Delivery Matrix Saving Method

\begin{tabular}{crr}
\hline SPBU Code & Phase 1 & Phase 2 \\
& 8 & 12 \\
34.41305 & 24 & 5 \\
34.41304 & 24 & 7 \\
34.41307 & 8 & 22 \\
34.41332 & 8 & 24 \\
34.41315 & 72 & 70 \\
\hline Total & &
\end{tabular}

Table 1. Distance SPBU Data

Table 2. Savings Matrix 
Table 3. Distance Saving Route

\begin{tabular}{ll}
\hline Route & Distance \\
\hline 4,5 & 5.4 \\
1,4 & 4.2 \\
1,5 & 3 \\
2,3 & 2.9 \\
2,5 & 2.9 \\
2,4 & 2.8 \\
1,2 & 2.1 \\
1,3 & 1.5 \\
\hline
\end{tabular}

Table 12. Transportation Costs Phase 1 Saving Matrix Method

\begin{tabular}{lrrrrr}
\hline Route & $\begin{array}{c}\text { Phase } 1 \\
\text { (Kiloliter) }\end{array}$ & $\begin{array}{c}\text { Cap. Tank } \\
\text { Truck } \\
\text { (Kilometer) }\end{array}$ & $\begin{array}{c}\text { Cost/KM } \\
\text { (Rp) }\end{array}$ & $\begin{array}{c}\text { Distance } \\
\text { From } \\
\text { Depot } \\
(\text { KM) }\end{array}$ & $\begin{array}{c}\text { Variable } \\
\text { Cost }\end{array}$ \\
\hline $0-4-5-1-0$ & 24 & 24 & 4,750 & 7.40 & 35,150 \\
$0-2-0$ & 24 & 24 & 4,750 & 14.60 & 69,350 \\
$0-3-0$ & 24 & 24 & 4,750 & 2.60 & 12,350 \\
\hline Total & 72 & & & 24.60 & 116,850 \\
\hline
\end{tabular}

Table 13. Transportation Costs Phase 2 Saving Matrix Method

\begin{tabular}{lrcrrr}
\hline Route & $\begin{array}{c}\text { Phase 2 } \\
\text { (Kiloliter) }\end{array}$ & $\begin{array}{c}\text { Cap. Tank } \\
\text { Truck } \\
\text { (Kilometer) }\end{array}$ & $\begin{array}{c}\text { Cost/KM } \\
\text { (Rp) }\end{array}$ & $\begin{array}{c}\text { Distance } \\
\text { From } \\
\text { Depot } \\
\text { (KM) }\end{array}$ & $\begin{array}{c}\text { Variable } \\
\text { Cost }\end{array}$ \\
\hline $0-4-0$ & 22 & 24 & 4,750 & 6 & 28,500 \\
$0-5-0$ & 24 & 24 & 4,750 & 6.4 & 30,400 \\
$0-1-2-3-0$ & 24 & 24 & 4,750 & 15.6 & 74,100 \\
\hline Total & 70 & & & 28 & 133,000 \\
\hline
\end{tabular}

Table 14. Number of Trucks used by the Saving Matrix Method

\begin{tabular}{cccccc}
\hline Vehicle & $\begin{array}{c}\text { Number of } \\
\text { Initial }\end{array}$ & Usage & Phase 1 & Phase 2 \\
\hline Premium & $24 \mathrm{KL}$ & 3 & 6 & 3 & 3 \\
\hline Total & 3 & 6 & 3 & 3 \\
\hline
\end{tabular}

Total Variable Cost $=$ Rp. 249,850

Total Fixed Cost $\quad=((3$ sopir $\times 168.000)+(3$ kernet $\times 160.000))$

$\begin{aligned} & =\text { Rp. } 984,000 \\ \text { Total Transpotation } & =\text { Total Variable Cost }+ \text { Total Fixed Cost }\end{aligned}$

$=$ Rp. $250,483+$ Rp. 984,000 


\section{Rifan Rizwan, Willy Rizkilah Ramdani, Muhammad Faisal Khobir and \\ Muchammad Fauzi}

$$
=\text { Rp. } 1,233,850
$$

From the calculations that have been carried out, the following results are obtained:

Table 4. Comparison of Calculation Results

\begin{tabular}{cccc}
\hline No & Comparison Factor & Initial Value & $\begin{array}{c}\text { Saving Matriks } \\
\text { Method }\end{array}$ \\
\hline 1 & Mileage & 63 & 53 \\
2 & Number of Vehicles & 7 & 3 \\
3 & Vehicle Usage & 9 & 6 \\
4 & Transportation Fee & $2,546,483$ & $1,233,850$ \\
\hline
\end{tabular}

\section{Conclussion}

Based on result and discussion can be concluded that the saving matrix method produces efficiency in total vehicle needs from 7 trucks to 4 tanker trucks, vehicle usage from 9 times to 6 times, distance traveled from $63 \mathrm{KM}$ to $53 \mathrm{KM}$ and the difference in transportation costs per day is Rp. 1,312,633.

\section{References}

Adriantantri, Emmalia, Irawan, Joseph Dedy, \& Indriani, Sri. (2015). Implementasi Metode Saving Matriks Pada Program Komputer Untuk Penentuan Pendistribusian Produk. Industri Inovatif: Jurnal Teknik Industri, 5(1), 10-14. Erlina, P. (2009). Mengoptimalkan Biaya Transportasi Untuk Penentuan Jalur Distribusi. Jurnal Penelitian Ilmu Teknik, 9(2), 143-150.

Istantiningrum, M. (2010). Penentuan Rute Pengiriman Dan Penjadwalan Dengan Menggunakan Metode Saving Matrix Study Kasus Pada Pt. Sukanda Djaya Yogyakarta. Program Studi Teknik.

Laksono, Ardiansyah Tri. (2017). Strategi Saluran Distribusi Telkomsel Distribution Center (Tdc) Telesindo Shop Di Banjarnegara.

Mardhiyah, Ainun, \& Safrin, Feby Aulia. (2020). Strategi Pemasaran Industri Rumah Tangga Keripik Singkong. Sketsa Bisnis, 7(1), 37-44.

Mochamad Arif Wibowo, Mochamad Arif Wibowo. (2019). Penentuan Rute Distribusi Amdk Menggunakan Pendekatan Heuristic Pada Capacitated Vehicle Routing Problem. Universitas Islam Majapahit Mojokerto.

Momon, Ade, \& Ardiatma, Damara Widi. (2018). Penentuan Rute Distribusi Suku Cadang Kendaraan Bermotor Dalam Meminimalkan Biaya Transportasi (Studi Kasus: Pt. Inti Polymetal Karawang). Journal Of Industrial Engineering And Management Systems, 11(1). 
Munawar, Ahmad. (N.D.). Transportasi: Peran Dan Dampaknya Dalam Pertumbuhan Ekonomi Nasional. Wahana Hijau, 121.

Salsabila, Nafila. (2021). Manajemen Distribusi Komoditas Harga Bahan Pangan Di Indonesia Dengan Metode Least Cost.

Supardi, Edi, \& Sianturi, Ruben Chandra. (2020). Metode Saving Matrix Dalam Penentuan Rute Distribusi Premium Di Depot Spbu Bandung. Jurnal Logistik Bisnis, 10(1), 89-98.

Suparjo, Suparjo. (2017). Metode Saving Matrix Sebagai Alternatif Efisiensi Biaya Distribusi (Studi Empirik Pada Perusahaan Angkutan Kayu Gelondongan Di Jawa Tengah). Media Ekonomi Dan Manajemen, 32(2).

Suryanto, Mikael Hang, \& Se, M. M. (2016). Sistem Operasional Manajemen Distribusi. Gramedia Widiasarana Indonesia.

Tyas, Rizki Ayuning, Dzulqarnain, Syahrizal, \& Aini, Qurrotul. (2020). Optimasi Jalur Distribusi Pada Kopkar Pt. Ykk Ap Indonesia Dengan Metode Saving Matrix. Sistemasi: Jurnal Sistem Informasi, 9(2), 215-225.

Yasmin, Yasmin, \& Wirawan, Panji Wisnu. (2018). Aplikasi Transportasi Multimodal Traveling Semarang Berbasis Web Menggunakan Graph Database Schema. Universitas Diponegoro.

$$
* * *
$$

\section{Copyright holder :}

Rifan Rizwan, Willy Rizkilah Ramdani, Muhammad Faisal Khobir and Muchammad Fauzi (2021)

First publication right :

Devotion - Journal of Community Service

This article is licensed under: 